\title{
Relative importance of location and period of banana bunch growth in carbohydrate content and mineral composition of fruit
}

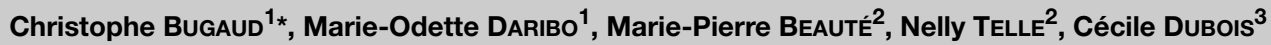

${ }^{1}$ CIRAD, UMR Qualisud, PRAM, BP 214,

97285 Lamentin Cedex 2, Martinique, France

bugaud@cirad.fr

${ }^{2}$ CIRAD, UPR 26, PRAM, BP 214, 97285 Lamentin Cedex 2, Martinique, France

${ }^{3}$ CIRAD, UPR 75 ,

Ave. Agropolis,

34398 Montpellier Cedex 5, France

${ }^{*}$ Correspondence and reprints

Received 30 May 2008 Accepted 19 September 2008

Fruits, 2009, vol. 64, p. 63-74 (C) 2009 Cirad/EDP Sciences All rights reserved DOI: 10.1051/fruits/2009001 www.fruits-journal.org

RESUMEN ESPAÑOL, p. 74
Relative importance of location and period of banana bunch growth in carbohydrate content and mineral composition of fruit.

Abstract - Introduction. Relationships between environmental conditions (climate and soil) and chemical characteristics of banana were studied in Martinique (French West Indies) to contribute to discussions about a quality label based on origin and to help to improve management of banana quality. Materials and methods. Bananas produced at six sites under different conditions and during three periods of the year were harvested at the same stage and ripened under identical conditions. Results. Differences in dry weight and chemical concentrations in the pulp of green fruits were greater between sites than between periods. The pulp dry weight was higher in fruits harvested at the highland site than in fruits harvested at the lowland sites. Differences in $\mathrm{Ca}$ and $\mathrm{Mg}$ were observed in fruits harvested on vertisol and andosol soils. Fruits produced on brown rust to halloysite soil contained high Mn concentrations. Differences in dry matter, total soluble solids and citric acid concentrations in the pulp of ripe fruits were greater between periods than between sites. Bananas harvested during the hot rainy season had the lowest pulp dry matter and total soluble solids. Bananas harvested during the cool dry season had the highest concentration of citric acid. Carbohydrate (dry matter, total soluble solids, and glucose and fructose) concentrations in fruit pulp decreased with an increase in mean daily temperature from bunch emergence to harvest. Conversely, mineral (P, Mg and $\mathrm{Ca}$ ) concentrations in fruit pulp increased with an increase in temperature. Conclusion. It is clear that these relationships should be taken into greater consideration when assessing banana quality. The specific environmental conditions in highland areas warrant the creation of a 'mountain banana' label.

France (Martinique) / Musa (bananas) / site factors / temperature / climate / soil types / fruit pulps / dry matter content / proximate composition

Importance relative du lieu et de la période de croissance des régimes de banane sur la composition des fruits en carbohydrates et éléments minéraux.

Résumé - Introduction. Les relations entre les conditions naturelles de production (sol, climat) et les caractéristiques chimiques des bananes ont été étudiées en Martinique, afin d'alimenter une réflexion sur la mise en place d'un label de qualité basé sur l'origine et d'aider la gestion de la qualité. Matériel et méthodes. Les fruits produits sur six sites, les plus divers possibles, et pendant trois périodes distinctes de l'année, ont été récoltés à la même somme thermique et mûris dans les mêmes conditions. Résultats. Les différences de poids sec et de composition minérale de la pulpe des fruits à la récolte ont été plus fortes entre les sites qu'entre les périodes. Le poids sec de la pulpe a été plus élevé dans les fruits récoltés sur le site en altitude que dans les fruits récoltés en plaine. Les fruits produits sur des sols de type vertisol ont été plus riches en calcium et magnésium que ceux produits sur des sols de type andosol. Les fruits produits sur des sols bruns rouille à halloysite ont été les plus riches en manganèse. Les différences de teneurs en matière sèche, extrait sec soluble et acide citrique dans la pulpe des fruits mûrs ont été plus fortes entre les périodes qu'entre les sites. Les bananes récoltées pendant la saison chaude et humide ont présenté les plus faibles teneurs en extrait sec soluble et total. Les bananes récoltées pendant la saison fraîche et sèche ont été les plus riches en acide citrique. Le poids sec de la pulpe, la teneur en matière sèche des fruits verts, l'extrait sec soluble et les concentrations en glucose et fructose dans les fruits mûrs ont diminué avec l'augmentation, pendant la croissance des fruits, de la température moyenne journalière. À l'inverse, les teneurs en phosphore, magnésium et calcium de la pulpe des fruits verts ont augmenté en même temps que l'augmentation de la température. Conclusion. Ces données devraient être prises en compte pour une meilleure compréhension de l'élaboration de la qualité des bananes. Les conditions environnementales spécifiques en altitude justifient la mise en place d'une dénomination "Montagne " pour la banane.

France (Martinique) / Musa (bananes) / facteur lié au site / température / climat / type de sol / pulpe de fruits / teneur en matière sèche / composition globale 


\section{Introduction}

Banana production is one of the main economic activities in the French West Indies (FWI). Faced with strong competition from other banana-exporting regions that benefit from lower production costs, the banana industry in the FWI needs to offer a new range of products to enhance market loyalty and sustainability. Banana producers in the region are proposing origin-based segmentation of the market.

Products such as wine and cheese are obviously associated with their regions of origin, but this is seldom true of fruits, especially bananas. There are few objective data to highlight differences in quality associated with site factors (soil, climate).

In immature green fruit, physiological differences are associated with the altitude of the plantation, the soil type and the season. Lowland bananas [50-100 $\mathrm{m}$ above sea level (a.s.l.)] are more susceptible to wound anthracnose caused by Colletotrichum musae than mountain bananas (> $300 \mathrm{~m}$ a.s.1.) [1]. In ripe bananas, studies in the FWI revealed physical and aromatic differences between mountain bananas and lowland bananas [2,3]. At the same harvest stage and under identical ripening conditions, mountain bananas had higher total soluble solids and higher citric acid content, firmer texture, and a higher concentration of aromatic compounds than lowland bananas. Recently, Bugaud et al. [4] showed a positive correlation between rainfall amount and fruit firm-

\section{Table I.}

Geographical characteristics of the six sites considered in Martinique (WFI) to study the relative importance of the location of banana bunch growth in the fruit composition.

\begin{tabular}{|c|c|c|}
\hline Sites / municipalities & Localisation & $\begin{array}{c}\text { Altitude } \\
\text { (m) }\end{array}$ \\
\hline Ajoupa-Bouillon & Lat. $14^{\circ} 48^{\prime} 44^{\prime \prime} \mathrm{N}$; long. $61^{\circ} 07^{\prime} 26^{\prime \prime} \mathrm{W}$ & 378 \\
\hline Basse-Pointe & Lat. $14^{\circ} 51^{\prime} 44^{\prime \prime} \mathrm{N}$; long. $61^{\circ} 07^{\prime} 03^{\prime \prime} \mathrm{W}$ & 55 \\
\hline Carbet & Lat. $14^{\circ} 43^{\prime} 33^{\prime \prime} \mathrm{N}$; long. $61^{\circ} 10^{\prime} 34^{\prime \prime} \mathrm{W}$ & 58 \\
\hline Lamentin & Lat. $14^{\circ} 37^{\prime} 18^{\prime \prime} \mathrm{N}$; long. $60^{\circ} 58^{\prime} 13^{\prime \prime} \mathrm{W}$ & 16 \\
\hline Saint-Joseph & Lat. $14^{\circ} 39^{\prime} 36^{\prime \prime} \mathrm{N}$; long. $60^{\circ} 59^{\prime} 49^{\prime \prime} \mathrm{W}$ & 40 \\
\hline Vauclin & Lat. $14^{\circ} 31^{\prime} 06^{\prime \prime} \mathrm{N}$; long. $60^{\circ} 50^{\prime} 18^{\prime \prime} \mathrm{W}$ & 14 \\
\hline
\end{tabular}

ness. This relationship could explain why bananas produced in highland areas, where rainfall is higher, were firmer. Physicochemical, nutritional and sensorial characteristics differ with the region of origin of the banana [5-7] and with the season [8]. Quality varies with production site, yet the causes of these variations remain to be determined. Moreover, in some cases, production practices (agronomic practices, harvest stage, ripening and storage) were not controlled, even though they have a clear impact on fruit traits [8-11]. Thus, to evaluate the impact of climate and soil conditions on the final quality of bananas, especially carbohydrate content and mineral composition, we conducted a year-long observational study in Martinique at several sites that are quite different in terms of soil and climatic conditions. The harvest stage, and ripening and storage conditions were kept identical throughout the study to reduce the impact of these factors on fruit traits. Our results contribute to discussions about a quality label based on origin and help to improve management of banana quality.

\section{Materials and methods}

\subsection{Characteristics of the studied sites and periods}

Our study was conducted under field conditions in six banana plantations belonging to different farms in Martinique (FWI) and during three growing periods of the years 2003-2004.

The selected sites were representative of six sets of climate and soil characteristics (tables I-III). The Ajoupa-Bouillon site, located in the highlands on young volcanic soil, had the highest amount of rain and the lowest mean daily temperature and sunlight. The Basse-Pointe and Carbet sites, which are located on volcanic soil too, differ in their amount of rainfall. The Lamentin and Saint-Joseph sites, which have a similar climate, have different soils: Lamentin is located on a continental alluvial soil and Saint-Joseph on a halloysitic soil. The Vauclin site, located on vertisol, had the highest 
Table II.

Soil chemical properties of the six sites considered in Martinique (WFI) to study the relative importance of the location of banana bunch growth in the fruit composition.

\begin{tabular}{|c|c|c|c|c|c|c|c|c|}
\hline \multirow[t]{2}{*}{ Sites } & \multirow[t]{2}{*}{ Soil ${ }^{1,2}$} & \multirow[t]{2}{*}{$\mathrm{pH}$} & \multirow[t]{2}{*}{$\begin{array}{l}\text { Organic matter } \\
\text { (g) }\end{array}$} & $\begin{array}{l}\text { Storage capacity } \\
\text { for cationic nutrients } \\
\text { (SCC) }\end{array}$ & $\mathrm{K}$ & $\mathrm{Ca}$ & $\mathrm{Mg}$ & \multirow[t]{2}{*}[\mathrm{K}/(\mathrm{K}+\mathrm{Ca}+\mathrm{Mg})]{} \\
\hline & & & & \multicolumn{4}{|c|}{$\left(\mathrm{cmolEq} \cdot \mathrm{kg}^{-1}\right)$} & \\
\hline Ajoupa-Bouillon & Andosol on ash and pumice & 5.1 & 11.6 & 10.3 & 0.7 & 1.0 & 1.0 & 27 \\
\hline Basse-Pointe & Immature on ash & 5.6 & 7.0 & 10.0 & 1.3 & 4.9 & 3.0 & 15 \\
\hline Carbet & Virgin andosol & 5.8 & 3.0 & 11.6 & 2.3 & 7.4 & 2.0 & 20 \\
\hline Lamentin & Continental alluvial & 5.4 & 3.2 & 30.1 & 1.6 & 17 & 11 & 5 \\
\hline Saint-Joseph & Brown rust to halloysite & 5.3 & 2.4 & 20.5 & 1.5 & 5.8 & 2.0 & 16 \\
\hline Vauclin & Vertisol & 6.4 & 6.8 & 53.8 & 9.0 & 38 & 26 & 12 \\
\hline
\end{tabular}

Table III.

Climatic conditions during banana bunch growth as a function of site and period (Martinique, FWI).

\begin{tabular}{|c|c|c|c|c|c|c|c|c|c|}
\hline \multirow[t]{2}{*}{ Sites } & \multicolumn{3}{|c|}{$\begin{array}{l}\text { Mean daily temperature } \\
\qquad\left({ }^{\circ} \mathrm{C}\right)\end{array}$} & \multicolumn{3}{|c|}{$\begin{array}{l}\text { Rainfall cumulated during banana } \\
\text { bunch growth } \\
(\mathrm{mm})\end{array}$} & \multicolumn{3}{|c|}{$\begin{array}{l}\text { Mean sunlight cumulated during banana } \\
\text { bunch growth } \\
\left(\mathrm{MJ} \cdot \mathrm{m}^{-2}\right)\end{array}$} \\
\hline & $\begin{array}{l}\text { Hot rainy } \\
\text { period }^{1}\end{array}$ & $\begin{array}{l}\text { Cool dry } \\
\text { period }^{2}\end{array}$ & Intermediate ${ }^{3}$ & $\begin{array}{l}\text { Hot rainy } \\
\text { period }\end{array}$ & $\begin{array}{l}\text { Cool dry } \\
\text { period }\end{array}$ & Intermediate & $\begin{array}{l}\text { Hot rainy } \\
\text { period }\end{array}$ & $\begin{array}{l}\text { Cool dry } \\
\text { period }\end{array}$ & Intermediate \\
\hline Ajoupa-Bouillon & 24.5 & 22.2 & 23.2 & 1231 & 1023 & 1073 & 1410 & 1620 & 1470 \\
\hline Basse-Pointe & 27.2 & 25.3 & 26.3 & 557 & 434 & 873 & 1580 & 1590 & 1720 \\
\hline Carbet & 27.3 & 25.4 & 26.3 & 449 & 257 & 484 & 1460 & 1560 & 1600 \\
\hline Lamentin & 27.2 & 25.4 & 26.3 & 542 & 340 & 673 & 1270 & 1520 & 1460 \\
\hline Saint-Joseph & 26.7 & 24.7 & 26.1 & 507 & 376 & 722 & 1350 & 1620 & 1370 \\
\hline Vauclin & 28.1 & 26.3 & 27.1 & 369 & 213 & 475 & 1480 & 1700 & 1770 \\
\hline
\end{tabular}

mean daily temperature and, with the Carbet site, the lowest amount of rainfall.

Three representative periods were chosen (table III): July to October 2003, which was the hot rainy period; December 2003 to March 2004, which was the cool dry period; and March to June 2004, which was an intermediate period. Actually, the hot rainy and intermediate periods had similar rainfall amounts. Mean daily temperatures, cumulated rainfall and daily sunlight were recorded for each farm based on data obtained from meteorological stations (CR10X, Campbell, Courtabœuf, France).

\subsection{Cultivation practices}

All the fields were planted with the cultivar Grande Naine, Cavendish subgroup (AAA). To reduce the impact of cropping cycles, especially plant crops, plants were grown on established fields [13]. Similar types and 
Table IV.

Age of banana fruit expressed as days and thermic sum [degree-days (dd)] as a function of site and period (Martinique, FWI).

\begin{tabular}{lcccccc} 
Sites & \multicolumn{2}{c}{ Hot rainy period } & \multicolumn{2}{c}{ Cool dry period } & \multicolumn{3}{c}{ Intermediate period } \\
\cline { 2 - 7 } & $\begin{array}{c}\text { Flowering-to-harvest time } \\
\text { (d) }\end{array}$ & $\begin{array}{c}\text { Fruit age } \\
\text { (dd) }\end{array}$ & $\begin{array}{c}\text { Flowering-to-harvest time } \\
\text { (d) }\end{array}$ & $\begin{array}{c}\text { Fruit age } \\
\text { (dd) }\end{array}$ & $\begin{array}{c}\text { Flowering-to-harvest time } \\
\text { (d) }\end{array}$ & $\begin{array}{c}\text { Fruit age } \\
\text { (dd) }\end{array}$ \\
Ajoupa-Bouillon & 95 & 995 & 118 & 1024 & 110 & 950 \\
Basse-Pointe & 78 & 1035 & 91 & 1030 & 86 & 1010 \\
Carbet & 77 & 1015 & 88 & 1000 & 83 & 1030 \\
Lamentin & 72 & 970 & 86 & 990 & 82 & 1025 \\
Saint-Joseph & 77 & 995 & 100 & 1050 & 89 & 1000 \\
Vauclin & 72 & 1020 & 92 & $1130^{1}$ & 87 & $1120^{1}$
\end{tabular}

${ }^{1}$ Bananas from the Vauclin site were harvested at over $1100 \mathrm{dd}$ for the last two periods because they had not reached the minimum diameter of $30 \mathrm{~mm}$ at $1000 \mathrm{dd}$.

quantities of fertiliser were applied: NPK [14 / 4 / 28], 100-120 g per application. The frequency of fertilisation depended on rainfall: every 3-4 weeks during the dry season (January-April) and every 2-3 weeks for the rest of the year. Fertiliser was applied to exceed nutrient cationic demand and to reach an optimal cationic balance in the soil. In the Vauclin soil, exchangeable potassium content was high to balance the two cations $\mathrm{Ca}$ and $\mathrm{Mg}$, which are naturally abundant. In the Lamentin soil, calcium was high but the balance with the other cations was satisfactory. All fields except the one located in Ajoupa-Bouillon were irrigated during the dry season. Depending on the amount of rainfall, $4-5 \mathrm{~mm}$ of water per day was supplied to each field by drip irrigation at the Basse-Pointe and Lamentin sites, by subcanopy sprinkler at the Carbet and Vauclin sites, and by overhead sprinkler in the SaintJoseph field. Other cropping practices (suckering, bunch management) were similar throughout the study period.

\subsection{Fruit sampling procedure}

In each field and at the beginning of each period, bunches were identified at the same inflorescence emergence stage on plants growing in a radius of $50 \mathrm{~m}$ from the centre of the plot and far from the borders. Of these bunches, five were randomly selected. The bunches were harvested at a temperature sum of 1000 degree-days (dd) $\pm 50 \mathrm{dd}$ (table IV), which was the mean daily temperature accumulated by the fruit during its growth from flowering to harvest with a baseline temperature of $14^{\circ} \mathrm{C}$ [14]. Bananas from the Vauclin site were harvested at over $1100 \mathrm{dd}$ in two of the three study periods because they had not reached a minimum diameter of $30 \mathrm{~mm}$ at $1000 \mathrm{dd}$. The fourth proximal banana hand per bunch was rinsed and dipped in fungicide (thiabenda$\mathrm{zol}, 500 \mathrm{mg} \cdot \mathrm{L}^{-1}$ ) for $1 \mathrm{~min}$. Half the hand was immediately used for measurements on green fruits.

\subsection{Fruit ripening and storage}

The other half of the hand was placed in a plastic bag with $20-\mu \mathrm{m}$ respiration holes and stored in packed boxes for 10-15 days at $14^{\circ} \mathrm{C}$, thus simulating the storage conditions commonly used during shipment from the FWI to European ripeners. Then, it was ripened with an ethylene treatment $\left(1 \mathrm{~mL} \cdot \mathrm{L}^{-1}\right.$ for $24 \mathrm{~h}$ at $16^{\circ} \mathrm{C}$ ). After $24 \mathrm{~h}$, the gassing room was ventilated. Bananas were maintained at $20{ }^{\circ} \mathrm{C}$ for 6 days until the "yellow" ripeness stage was reached [15], which corresponds to the edible stage preferred by consumers. 


\subsection{Physicochemical analyses}

Fruits and pulp of green fruit were weighed. To measure dry matter content in pulp of green and ripe fruits, $2 \mathrm{~g}$ of purée was ovendried at $70{ }^{\circ} \mathrm{C}$ for $24 \mathrm{~h}$ and then weighed. Total soluble solids in ripe fruits were measured by refractometry after centrifugation $(9,300 \mathrm{~g}$ for $10 \mathrm{~min})$. The supernatant was frozen at $-20{ }^{\circ} \mathrm{C}$ for subsequent analysis of sugar and acid concentrations. The sugar (sucrose, glucose and fructose) and acid (malic and citric acid) concentrations were analysed by HPLC as described by Bugaud et al. [2]. The mineral composition ( $\mathrm{K}, \mathrm{Mg}$, $\mathrm{P}, \mathrm{Ca}, \mathrm{Fe}, \mathrm{Zn}$ and $\mathrm{Mn}$ ) of dry matter from the pulp of green fruits was analysed according to the method described by Martin-Prével et al. [16]. For carbohydrates, five samples - one for each of the five bunches selected - were analysed separately. For minerals, the dry pulp of green fruits from the five bunches was pooled into a single sample. Each analytical sample was analysed twice and results were averaged.

\subsection{Statistical analyses}

Means of the carbohydrate contents of the five samples (site $\times$ period) were calculated in order to use the same statistical model for all physicochemical quantities. Main effects were tested by a two-way analysis of variance: field (six levels) $\times$ period (three levels). Without true replicates, the interaction field $\times$ period could not be tested and is considered as a random error term. Means were compared with Tukey's multiple range test at the 5\% significance level (Minitab software package, release 13.20, 2000).

\section{Results}

\subsection{Effect of periods and sites on carbohydrate and mineral composition}

At harvest, fruit and pulp dry weights of green bananas differed significantly between sites $(P<0.001)$ (table V). The pulp dry weight of fruits harvested at the Ajoupa-Bouillon site was the highest, i.e., from (40 to 130)\% higher than pulp dry weight of fruits harvested at the other sites. Fruits harvested in the hot rainy period had lower significant pulp dry weight than that of fruits harvested in the intermediate period $(P<0.05)$. The fruit weight was correlated with pulp dry weight $(R=0.97 ; P<0.001)$. The dry matter contents in the pulp of green bananas were significantly lowest in the hot rainy period $(P<0.001)$.

In ripe fruit pulp, the dry matter and total soluble solids contents were significantly lowest in the hot rainy period $(P<0.001)$. Average differences in dry matter content for the two other periods were more than $20 \mathrm{~g} \cdot \mathrm{kg}^{-1}$ fresh weight. For total soluble solids content, the difference was close to $3{ }^{\circ}$ Brix, to the advantage of bananas harvested in the cool dry period. Dry matter contents of green bananas were correlated with the dry matter $(R=0.90 ; P<0.001)$ and total soluble solids contents $(R=0.89$; $P<0.001)$ of ripe bananas.

No significant differences in total soluble sugars were observed among sites and periods. Only fruits harvested at the hottest site (Vauclin) had significantly lower fructose concentrations than fruits harvested at the Ajoupa-Bouillon and Basse-Pointe sites $(P<0.05)$. The mean [glucose / fructose] and [sucrose/glucose + fructose] ratios were approximately equal to 1 .

The citric and malic acid concentrations were significantly higher in the pulp of ripe bananas harvested during the cool dry period than those harvested during the hot rainy period $(P<0.001$ and $P<0.05$, respectively). The concentrations of malic acid were significantly higher in Vauclin bananas than in Ajoupa-Bouillon, BassePointe and Lamentin bananas $(P<0.05)$.

Magnesium concentrations in green fruits harvested at the Vauclin site were significantly higher than magnesium concentrations found in green fruits harvested at the Ajoupa-Bouillon, Lamentin or Saint-Joseph sites $(P<0.001)$ (table VI). Differences in magnesium concentrations between Vauclin and Ajoupa-Bouillon bananas reached as much as $0.30 \mathrm{~g} \cdot \mathrm{kg}^{-1}$ dry weight. Calcium 


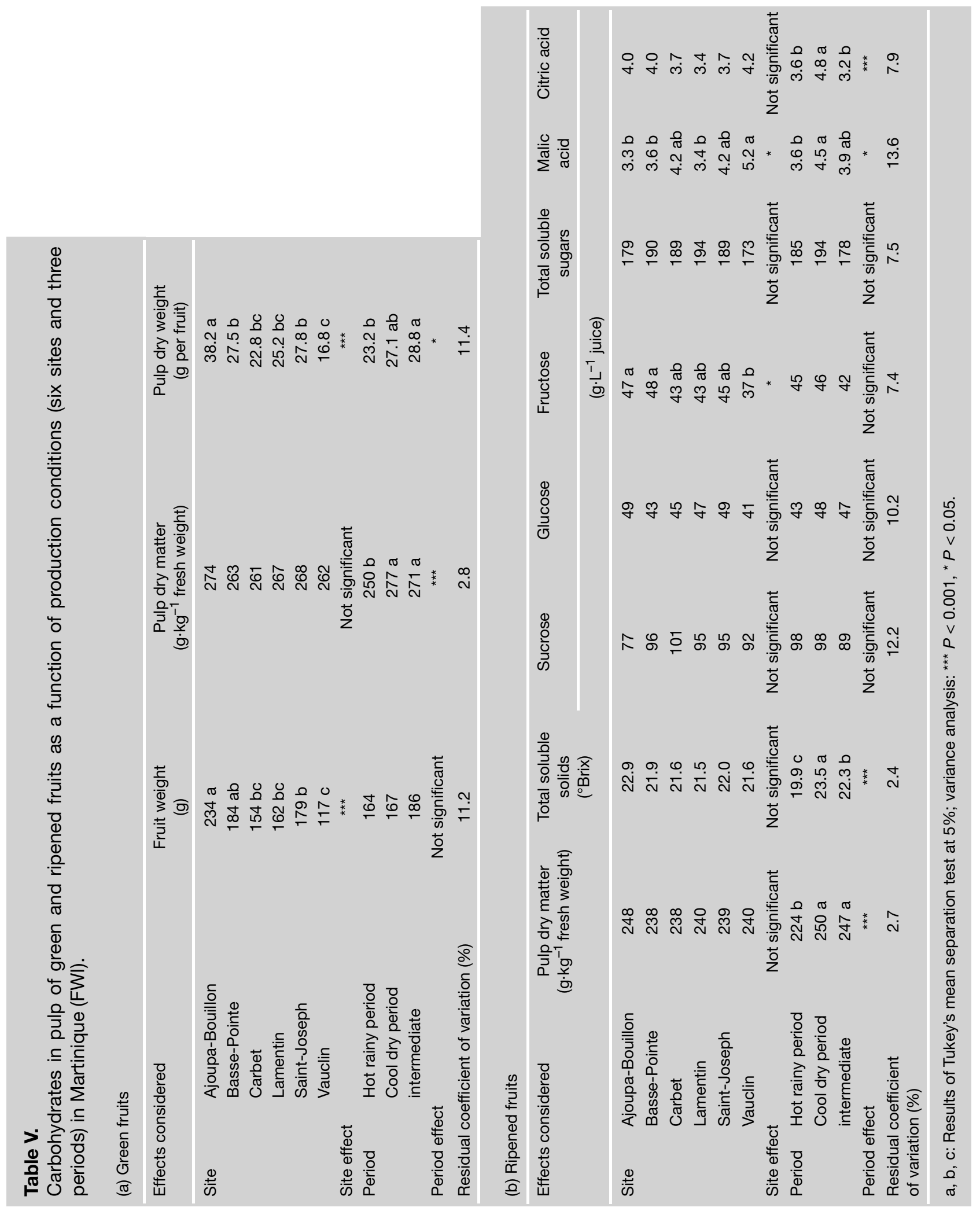


Table VI.

Mineral composition in pulp of green fruits as a function of production conditions (six sites and three periods) in Martinique (FWI).

\begin{tabular}{|c|c|c|c|c|c|c|c|c|}
\hline \multirow{3}{*}{\multicolumn{2}{|c|}{ Effects considered }} & \multicolumn{4}{|c|}{ Macro-element } & \multicolumn{3}{|c|}{ Micro-element } \\
\hline & & Potassium & Magnesium & Phosphorus & Calcium & Iron & Zinc & Manganese \\
\hline & & \multicolumn{4}{|c|}{$\mathrm{g} \cdot \mathrm{kg}^{-1}$ pulp dry matter } & \multicolumn{3}{|c|}{$\mathrm{mg} \cdot \mathrm{kg}^{-1}$ pulp dry matter } \\
\hline \multirow[t]{6}{*}{ Site } & Ajoupa-Bouillon & 13.3 & $1.16 \mathrm{~b}$ & 0.72 & $0.16 \mathrm{c}$ & 15 & 12 & $3 \mathrm{~b}$ \\
\hline & Basse-Pointe & 15.9 & $1.26 \mathrm{ab}$ & 0.88 & $0.19 \mathrm{bc}$ & 21 & 9 & $5 b$ \\
\hline & Carbet & 15.5 & $1.28 \mathrm{ab}$ & 0.96 & $0.20 \mathrm{bc}$ & 19 & 11 & $9 \mathrm{~b}$ \\
\hline & Lamentin & 13.4 & $1.23 \mathrm{~b}$ & 0.80 & $0.35 a$ & 23 & 9 & $11 \mathrm{~b}$ \\
\hline & Saint-Joseph & 14.0 & $1.23 b$ & 0.84 & $0.26 a b c$ & 17 & 9 & $38 \mathrm{a}$ \\
\hline & Vauclin & 15.5 & $1.46 \mathrm{a}$ & 1.09 & $0.29 \mathrm{ab}$ & 22 & 10 & $18 \mathrm{~b}$ \\
\hline \multicolumn{2}{|c|}{ Site effect } & Not significant & *** & ns & *** & ns & ns & *** \\
\hline \multirow[t]{3}{*}{ Perio } & Hot rainy period & $15.9 a$ & 1.32 & 0.95 & 0.27 & 20 & 11 & 16 \\
\hline & Cool dry period & $14.2 \mathrm{ab}$ & 1.25 & 0.82 & 0.22 & 20 & 10 & 14 \\
\hline & intermediate & $13.8 b$ & 1.24 & 0.88 & 0.23 & 19 & 10 & 13 \\
\hline \multicolumn{2}{|c|}{ Period effect } & * & Not significant & Not significant & Not significant & Not significant & Not significant & Not significant \\
\hline \multicolumn{2}{|c|}{$\begin{array}{l}\text { Residual coefficient of } \\
\text { variation }(\%)\end{array}$} & 8.2 & 6.0 & 14.5 & 16.6 & 22.5 & 16.9 & 40.2 \\
\hline
\end{tabular}

concentrations were significantly twofold higher in Lamentin bananas than in AjoupaBouillon bananas $(P<0.001)$. Manganese concentrations were significantly two- to tenfold higher in fruits grown at the SaintJoseph site than in fruits grown at the other sites $(P<0.001)$. Mineral concentrations were the highest in the pulp of green fruits harvested during the hot rainy period (table VI). These differences were significant for potassium only $(P<0.05)$.

\subsection{Correlation between climatic parameters and chemical composition of ripe fruit}

The pulp dry weight in fruits increased with a decrease in the mean daily temperature during bunch growth $(R=-0.83 ; P<0.001)$ (figure 1). A negative correlation was observed between the mean daily temperature during bunch growth and the dry matter content in pulp of green and ripe fruits $(R=-0.67$ and $R=-0.62 ; P<0.01$, respectively) and the total soluble solids contents

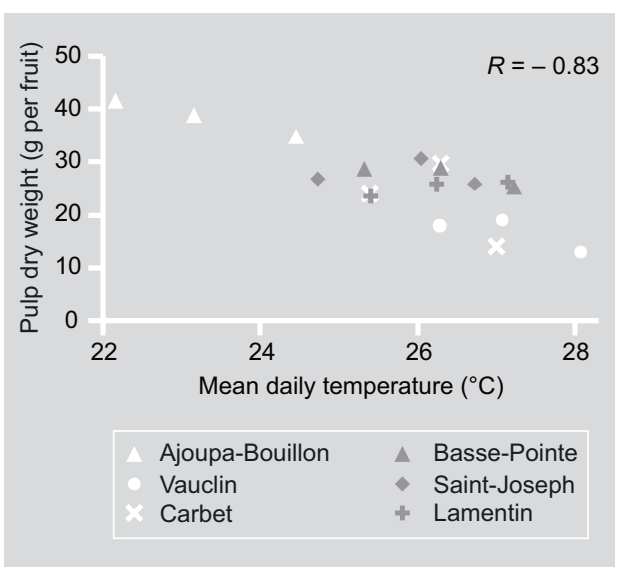

Figure 1.

Correlation between mean daily temperature during bunch growth and pulp dry weight of banana at harvest. Each point is the mean of fruits from five bunches.
( $R=-0.72 ; P<0.001$ ) (figures 2,3$)$. When disregarding the values for the AjoupaBouillon site, these correlations increased to $R=-0.79, R=-0.77$ and $R=-0.84$, respectively $(P<0.001)$. No correlation was observed between sunlight cumulated during bunch growth and pulp dry weight and matter content. The glucose and fructose concentrations decreased with an increase 
Figure 2.

Correlation between mean daily temperature during bunch growth and dry matter of banana at harvest. Each point is the mean of fruits from five bunches.

\section{Figure 3.}

Correlation between mean daily temperature during bunch growth and total soluble solids of ripened banana. Each point is the mean of fruits from five bunches.

\section{Figure 4.}

Correlation between mean daily temperature during bunch growth and the glucose and fructose concentrations of ripened banana. Each point is the mean of fruits from five bunches.
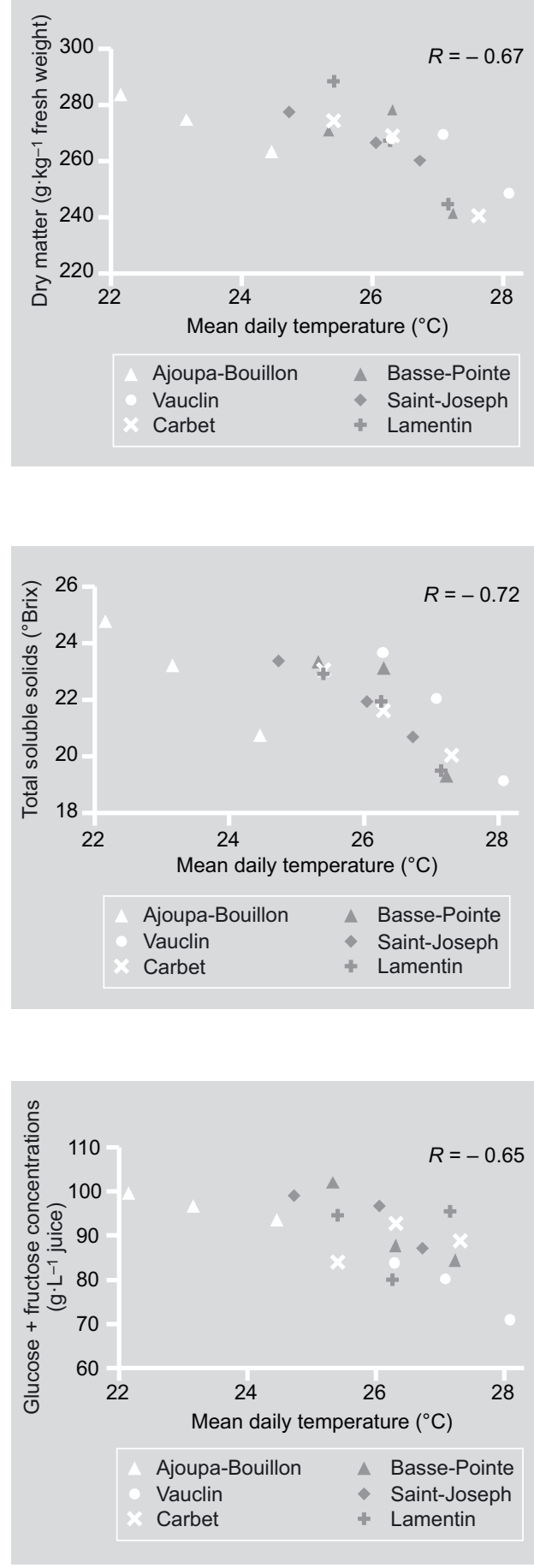

in the mean daily temperature during bunch growth $(R=-0.65 ; P<0.01)$ (figure 4$)$. A positive correlation was observed between mean daily temperature during bunch growth and macro-element concentrations ( $R=0.67$ for phosphorus, $R=0.64$ for magnesium, $R=0.61$ for calcium; $P<0.01$ ) (figure 5).

\section{Discussion}

We chose to work under real environmental conditions in order to study a wide range of sites, i.e., as diversified as possible. Our experiment thus enabled us to classify the effects of the site and of the production period on the physicochemical characteristics of banana grown under given conditions. However, due to the lack of replicates (similar sites studied over a period of several years), our results should be interpreted with care. A study in controlled conditions will be required to confirm the differences that we recorded here.

Concerning chemical composition, differences between sites were greater than differences between periods. These differences were not insignificant for two macroelements ( $\mathrm{Mg}$ and $\mathrm{Ca}$ ) and one micro-element (Mn). If the objective is to promote geographic origin, the micro-element $\mathrm{Mn}$, which is particularly involved in the formation of bone, is of great interest. We observed that a fruit produced on brown rust to halloysite soil (Saint-Joseph site) contained more than $1 \mathrm{mg}$ of $\mathrm{Mn}$, which would cover more than half the daily recommended intake of $\mathrm{Mn}$ [17]. Concerning Ca and $\mathrm{Mg}$, recorded differences were smaller. Moreover, the quantities recorded in the fruits analysed $(<7 \mathrm{mg}$ for $\mathrm{Ca}$ and $<45 \mathrm{mg}$ for $\mathrm{Mg}$ ) were far below the recommended dietary allowance $\left(1300 \mathrm{mg} \cdot \mathrm{d}^{-1}\right.$ for $\mathrm{Ca}$ and $400 \mathrm{mg} \cdot \mathrm{d}^{-1}$ for $\mathrm{Mg}$ ) [17].

At the same harvest stage (about 1000 degree-days), differences in fruit and pulp dry weights were greater between sites than between periods. The fact that the biggest and heaviest fruits were harvested in the highland area is in good agreement with the results of Bugaud et al. [2] and Chillet et al. [18], and is favourable for the creation of a mountain label.

Concerning sugar and acid concentrations, there was a clear impact of period. 
Bananas produced during the cool dry period had higher total soluble solids contents and malic and citric acid concentrations than bananas produced during the hot rainy period. These results are in accordance with those of Ambuko et al. [8]. However, there is no evidence that the differences in total soluble solids and in acid concentrations between periods would be detected by consumers. Indeed, Cano et al. [5] observed that panellists were only able to differentiate the sweet taste of bananas when differences in total soluble solids contents were about $5^{\circ}$ Brix.

The negative correlation between the accumulation of pulp dry weight in fruit and the mean daily temperature during bunch growth confirmed previous results obtained by other authors [19, 20]. At constant sunlight and a $1030 \mathrm{dd}$ temperature sum, Jullien demonstrated that a $2{ }^{\circ} \mathrm{C}$ increase in mean daily temperature led to a $5 \%$ decrease in pulp dry weight [19]. According to Jullien [19] and Marcelis [21], the fruit filling rate, which is one determining factor of dry matter accumulation, should decrease with increasing temperature when photosynthesis is a limiting factor. Pulp dry matter, like pulp dry weight, decreased with an increase in mean daily temperature. However, we observed a difference in dry matter between the fruits from the highland site (AjoupaBouillon) and the others. Jullien et al. observed a decrease in pulp dry matter content after $1030 \mathrm{dd}$ [22], which was not related to starch hydrolysis. It is possible that the decrease in pulp dry matter began sooner in Ajoupa-Bouillon fruits. It would be necessary to monitor pulp dry matter content during bunch growth to clarify this hypothesis.

The negative correlation between the mean daily temperature and sugar contents, which are the main components of total soluble solids of ripened fruit, is certainly the consequence of the links between temperature and dry matter in green fruit. As starch is the major component of dry weight in green fruit, an increase in dry matter would logically be accompanied by an increase in starch, which is mainly converted into sugar during ripening. Subsequently, the more starch there is in green fruit, the more sugars

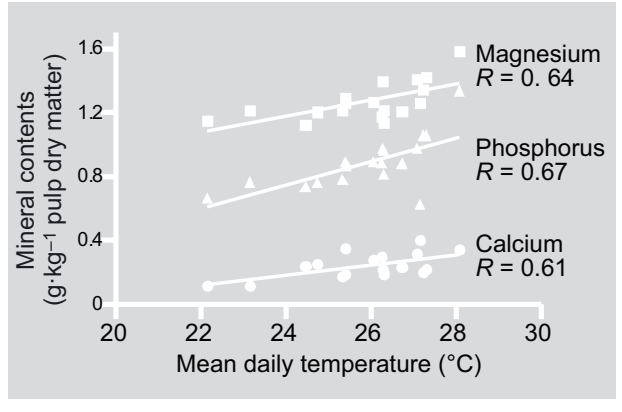

Figure 5.

Correlation between mean daily temperature during bunch growth and the mineral contents of green banana pulp. would be expected in ripe fruits, particularly glucose and fructose, whose concentrations are maximum at full ripeness [23].

Climatic conditions, soil composition and cultivation practices are known to influence the chemical composition of fruits [24-29]. In our study, we attempted to reduce the impact of certain factors such as water stress [27] and fertilisation [25, 26] by irrigating during dry periods and by applying similar types and quantities of fertilisers at all sites.

Among climatic factors, temperature could affect the chemical composition of banana fruits. To our knowledge, a positive correlation between mean daily temperature and phosphorus, magnesium and calcium contents has not previously been reported in banana fruits. However, Turner and Lahav [30] found a similar effect of temperature on nutrient concentrations in banana leaves. These authors reported that, under subtropical conditions, as temperatures rose, absorption of nutrients in most tissues increased more than might be expected from a change in growth rate due to an increase in temperature, while the efficiency of their use for plant growth decreased. These relationships between temperature and mineral contents in banana pulp could explain their high values in fruits harvested during the hot period and at the hottest site (Vauclin) in our study.

Other environmental factors such as the chemical characteristics of the soil could also affect the mineral composition of banana fruits $[28,29]$. The differences in cation contents, particularly calcium and magnesium, among sites could be partially explained by the nature of soil components and nutrient concentration of the soil. 
Vertisols, like those at the Vauclin site, have a good storage capacity for cationic nutrients, while andosols on ash and pumice, i.e., those at the Ajoupa-Bouillon site, have a low cation exchange capacity [31]. At the Lamentin site, the high exchangeable calcium contents measured in the soil (table II) could explain their high values in the fruits. The high manganese contents in fruits grown at the Saint-Joseph site may be the result of high concentrations of available manganese in the brown rust to halloysite soil. When studying variations in the susceptibility of bananas to wound anthracnose, Chillet et al. [1] showed that fruits produced on halloysitic and ferrallitic soils presented high manganese concentrations in peel.

\section{Conclusion}

Despite the difficulty in interpreting our data due to possible interactions between different factors, this study revealed differences in the chemical composition of fruits linked with climate and soil conditions. An experimental study in controlled conditions is now required to confirm their direct effects and to identify the exact mechanisms involved. Nevertheless, it is clear that these relationships should be taken into greater consideration when assessing banana quality. The specific environmental conditions in highland areas warrant the creation of a 'mountain banana' label.

\section{Acknowledgements}

Financial support was provided by Structural European Funds. The authors are grateful to the following growers for access to their banana fields: MM. Dagiste, De Reynal, Gros-Dubois and Marraud Des Grottes.

\section{References}

[1] Chillet M., de Lapeyre de Bellaire L., Dore M., Joas J., Dubois C., Marshal J., Perrier X., Evidence for the variation in susceptibility of bananas to wound anthracnose due to Colletotrichum musae and the influence of edaphic conditions, Sci. Hortic. 86 (2000) 33-47.

[2] Bugaud C., Chillet M., Beauté M.P., Dubois C., Physicochemical analysis of mountain bananas from the French West Indies, Sci. Hortic. 108 (2006) 167-172.

[3] Brat P., Yahia A., Chillet M., Bugaud C., Bakry F., Reynes M., Brillouet J.M., Influence of cultivar and growth altitude on banana volatile compounds distribution, Fruits 59 (2004) 75-82.

[4] Bugaud C., Daribo M.O., Dubois C., Climatic conditions affect the texture and colour of Cavendish bananas (Grande Naine cultivar), Sci. Hortic. 113 (2007) 238-243.

[5] Cano M.P., de Ancos B., Matallana M.C., Camara M., Reglero G., Tabera J., Differences among Spanish and Latin-American banana cultivars: morphological, chemical and sensory characteristics, Food Chem. 59 (1997) 411-419.

[6] Hardisson A., Rubio C., Baez A., Martin M., Alvarez R., Diaz E., Mineral composition of the banana (Musa acuminata) from the island of Tenerife, Food Chem. 73 (2001) 153-161.

[7] Hughes P.A., Wainwright H., Influence of site and fruit position on the pulp colour and texture of bananas, Trop. Sci. 34 (1994) 211215.

[8] Ambuko J.L., Sekozawa Y., Sugaya S., Itoh F., Nakamura K., Gemma H., Effect of seasonal variation, cultivar and production system on some postharvest characteristics of the banana, Acta Hortic. 712 (2006) 505510.

[9] Ahmad S., Thompson A.K., Ahmad H.I., Asghar A.A., Effect of temperature on the ripening behaviour and quality of banana fruit, Int. J. Agric. Biol. 3 (2001) 224-227.

[10] Layliam S., Kosittrakun M., Effects of harvest maturity on banana quality, J. Food Qual. 22 (1998) 539-544.

[11] Smith N.J.S., Thompson A.K., The effects of temperature, concentration and exposure time to acetylene on initiation of banana ripening, J. Sci. Food Agric. 40 (1987) 43-50.

[12] Colmet-Daage M.F., Carte des sols à $1 / 20$ 000 de la Martinique, 24 feuilles $26 \mathrm{~cm} \times$ $70 \mathrm{~cm}$, ORSTOM, Fort de France, France, 1970. 
[13] Baiyeri K.P., Tenkouano A., Fruit characteristics and ripening pattern of ten Musa genotypes in a sub-humid environment in Nigeria, Fruits 63 (1) (2008) 3-9.

[14] Ganry J., Meyer J.P., Recherche d'une loi d'action de la température sur la croissance des fruits du bananier, Fruits 30 (1975) 375392.

[15] Von Loesecke H.W., Bananas, Interscience, New York, USA, 1950.

[16] Martin-Prével P., Gagnard J., Gautier P., L'analyse végétale dans le contrôle de l'alimentation des plantes tempérées et tropicales, Tech. Doc., Lavoisier, Paris, France, 1984.

[17] Trumbo P., Yates A.A., Schlicker S., Poos M., Dietary reference intakes: vitamin $A$, vitamin $\mathrm{K}$, arsenic, boron, chromium, copper, iodine, iron, manganese, molybdenum, nickel, silicon, vanadium, and zinc, J. Am. Diet. Assoc. 101 (2001) 294-301.

[18] Chillet M., Hubert O., Rives J.M., de Lapeyre de Bellaire L., Effects of the physiological age of bananas on their susceptibility to wound anthracnose due to Colletrichum musae, Plant Dis. 90 (2006) 1181-1185.

[19] Jullien A., Croissance, développement et qualité des fruits du bananier (Musa spp. groupe AAA, cv. Grande Naine). Modélisation de la répartition des assimilats entre les fruits du Régime, Inst. Natl. Agron., Thèse, Paris-Grignon, France, 2000, 92 p.

[20] Turner D.W., Lahav E., The growth of banana plants in relation to temperature, Aust. J. Plant Physiol. 10 (1983) 43-53.

[21] Marcellis L.F.M., Sink strength as a determinant of dry matter partitioning in the whole plant, J. Exp. Bot. 47 (2001) 1281-1291.

[22] Jullien A., Malézieux E., Michaux-Ferrière N., Chillet M., Ney B., Within-bunch variability in banana fruit weight: importance of developmental lag between fruits, Ann. Bot. 87 (2001) 101-108.
[23] Chang W.H., Hwang Y.J., Effect of some inhibitors on carbohydrate content and related enzyme activity during ripening of Taiwan northern banana fruit, Acta Hortic. 275 (1990) 611-619.

[24] Woolf A.B., Ferguson I.B., Postharvest responses to high fruit temperatures in the field, Postharvest Biol. Technol. 21 (2000) 7-20.

[25] Turner D.W., Barkus B., Yield, chemical composition, growth and maturity of 'Williams' banana fruit in relation to supply of potassium, magnesium and manganese, Sci. Hortic. 16 (1982) 239-252.

[26] Nyanjage M.O., Wainwright H., Bishop C.F.H., Cullum F.J., A comparative study on the ripening and mineral content of organically and conventionally grown Cavendish bananas, Biol. Agric. Hortic. 18 (2001) 221-234.

[27] Hedge D.M., Srinivas K., Effect of soil moisture stress on fruit growth and nutrient accumulation in banana cultivar 'Robusta', Fruits 44 (1989) 135-138.

[28] Thorp T.G., Hutching D., Lowe T., Marsch K.B., Survey of fruit mineral concentrations and postharvest quality of New Zealandgrown 'Hass' avocado (Persea americana Mill.), N. Z. J. Crop Hortic. Sci. 25 (1997) 251-260.

[29] Ribeira de Lima M.T., Cabanis M.T., Cassana G., Matos L., Pinheiro J., Cabanis J.C., Blaise A., Volcanic soils composition impact on the major mineral elements content of grapes and wines, J. Int. Sci. Vigne Vin 37 (2003) 171-179.

[30] Turner D.W., Lahav E., Temperature influences nutrient absorption and uptake rates of bananas grown in controlled environments, Sci. Hortic. 26 (1985) 311-322.

[31] Delvaux B., Soils, in: Gowen S. (Ed.), Bananas and plantains, Chapman \& Hall, London, UK, 1995. 
Importancia relativa al lugar y al periodo de crecimiento de los regímenes de banano frente a la composición de los frutos en carbohidratos y en elementos minerales.

Resumen - Introducción. Se estudió en Martinica las relaciones existentes entre las condiciones naturales de producción (suelo, clima) junto con las características químicas de los bananos, con el fin de alimentar una reflexión sobre la instauración de un sello de calidad basado en el origen y de ayudar a la gestión de la calidad. Material y métodos. Los frutos, producidos en seis zonas lo más diversas posibles, y durante tres periodos del año diferentes, se cosecharon en el mismo valor térmico y madurados bajo las mismas condiciones. Resultados. Las diferencias de peso en seco y de composición mineral de la pulpa de los frutos durante la cosecha fueron mayores entre las zonas que entre los periodos. El peso seco de la pulpa fue más elevado en aquellos frutos cosechados en la zona en altitud que en aquellos frutos cosechados en llanura. Los frutos producidos sobre suelos de tipo vertisol fueron más ricos en calcio y en magnesio que aquellos producidos sobre suelos de tipo andosol. Los frutos producidos sobre suelos pardos de halloysita fueron más ricos en magnesio. Las diferencias del contenido en materia seca, extracto seco soluble y ácido cítrico en la pulpa de los frutos maduros fueron más pronunciadas entre los periodos que entre las zonas. Los bananos cosechados durante la estación cálida y húmeda presentaron los contenidos más flojos en extracto seco soluble y total. Los bananos cosechados durante la estación fresca y seca fueron los más ricos en ácido cítrico. El peso seco de la pulpa, el contenido en materia seca de los frutos verdes, el extracto seco soluble así como las concentraciones en glucosa y fructosa en los frutos maduros disminuyeron con el aumento, durante el crecimiento de los frutos, de la temperatura media diaria. Por el contrario, los contenidos en fósforo, magnesio y en calcio de la pulpa de los frutos verdes aumentaron al mismo tiempo que el aumento de la temperatura. Conclusión. Estos datos deberían tomarse en cuenta para una comprensión mejor de la elaboración de la calidad de los bananos. Las condiciones medioambientales específicas en altitud justifican la instauración de una denominación "Montaña " para el banano.

Francia (Martinica) / Musa (bananos) / características del sitio / temperatura / clima / tipos de suelos / pulpa de frutas / contenido de materia seca / composición aproximada 